\title{
SOME NEW CALISTO FROM HISPANIOLA AND CUBA (LEPIDOPTERA: SATYRIDE)*
}

\author{
By Harry K. Clench \\ Cambridge, Mass.
}

The following new Calisto are based upon material collected during the past few years by M. Bates, P. J. Darlington, and C. T. Parsons on various expeditions for the Museum of Comparative Zoölogy.

\section{Calisto batesi, new species}

\section{Upperside:}

Male. Blackish brown, deeper toward the base of the hind wing. Fore wing with a large area of jet black, covering the basal two-thirds of the wing.

\section{Underside:}

Male. Both wings grayish brown, base of the hind wing slightly darker. Fore wing with two submarginal lines (the inner one heavier) and a discal line. Near the costa, between the latter and the basal one of the former, there is a black, yellow-ringed ocellus, with two minute white pupils within. Cell with a large red patch, extending from near base almost to cell-end. Hind wing with a post-basal, discal and two submarginal lines, the latter both badly dislocated at each intersection with a vein. The discal line approaches these and almost meets them at the anal angle. Between the discal and the submarginal lines, in the $\mathrm{Cu}_{1}-\mathrm{Cu}_{2}$ interspace, is a tiny ocellus, black, yellow rimmed, as in that of the fore wing, but here with only one central white pupil. Between the same lines, but in the $\mathbf{M}_{2}-\mathbf{M}_{3}-$ $\mathrm{Cu}_{1}$ interspaces, are two small white spots, placed parallel to the body line, rather than to the outer margin.

Length of fore wing, $14 \mathrm{~mm}$.

Holotype, male, Loma del Toro, foothills of the Cordillera

* Published with the aid of a grant from the Museum of Comparative Zoology, Harvard College. 
Central, south of Santiago, Republica Dominicana, Hispaniola, \pm 5000 feet, June 1938 (P. J. Darlington). M. C. Z. no. 25915. Remarks. Calisto batesi differs from the related grannus ${ }^{1}$ in several points. The cell of the fore wing below is concolorous with the ground, while in grannus it is red. The ocellus of the fore wing below is smaller than in grannus (even smaller than in the paratypes of grannus from Loma Rucilla, Rep. Dom., whose ocelli were noted by Bates to be smaller than those of the remaining (Valle Nuevo, Rep. Dom.) paratypes). On the hind wing below batesi may be distinguished from grannus by the absence of the apical ocellus and the greatly reduced size of the anal one. The discal line appears to be lighter in batesi than in grannus (on both wings below), and on the hind wing arises closer to the center of the costa. Possibly this species is intermediate between grannus and tragius, ${ }^{2}$ since to the latter it also bears a resemblance. However, tragius has a ruddy patch below the apical ocellus of the fore wing, and on the hind wing has the inner and outer marginal areas shaded with light scales.

This species is named for Dr. Marston Bates, who has contributed so much to our knowledge of this genus.

\section{Calisto hysius montana, new subspecies}

\section{Upperside:}

Male. Dark black-brown. A small obscure ruddy patch occupies an area near the anal angle of the hind wing.

\section{Underside:}

Male. Both wings black-brown. Fore wing with the cell completely red, this color extending slightly into the neighboring interspaces. Two very faint submarginal lines and a faint discal line cross the wing. Between the inner submarginal and the discal is a black, bi-pupilled ocellus, ringed with yellowish. Hind wing irrorated with light scales, strongly near the inner margin, lightly elsewhere. Two submarginal lines as in the fore wing, but more prominent. A single circular and nearly symmetrical ocellus lies in the $\mathrm{Cu}_{1}-\mathrm{Cu}_{2}$ area just behind the inner submarginal line. Basal to this inner submarginal line is

\footnotetext{
${ }^{1}$ Bates, 1939, Psyche 46, p. 49 (Notes on Butterflies from Hispaniola).

${ }^{2}$ Bates, 1935, Occ. Papers Boston Soc. Nat. Hist. 8, p. 236, fig. 3 (The Satyrid Genus Calisto).
} 
an obscure purplish band, in which, besides the ocellus, are three white spots, one each in the $\mathrm{M}_{2}-\mathrm{M}_{3}-\mathrm{Cu}_{1}$ interspaces. Basal to the ocellus is an obscure discal line, and still further basad is another line, the latter composed solely of whitish scales. Anal angle with a small black spot.

Length of fore wing, $15 \mathrm{~mm}$.

Holotype, male, Mt. Basil, Haiti, 4500 feet, September 9, 1934 (P. J. Darlington and M. Bates), M. C. Z. no. 25914.

Remarks. This subspecies differs from typical hysius ${ }^{3}$ (as represented by the series identified by Bates as typical) in lacking the red patch below the subapical ocellus of the fore wing; in the marginal extension of the red into the outer extremity of the cell below; in the white post-median line on the hind wing below, which in the typical is less prominent and bordered with blackish; and in the slightly larger subapical ocellus on the underside of the fore wing. Also, the subanal ocellus of the hind wing below is more nearly round, and has the pupil almost in the center, while in hysius the ocellus is oval, with the pupil towards the base.

\section{Calisto confusa debarriera, new subspecies}

Calisto hysius: Lathy, 1899, Trans. Ent. Soc. London 1899, p. 226, pl. 4, figs. 10, 11 (A Monograph of the Genus Calisto, Hübn.).

Calisto confusa: Bates, 1935, Occ. Papers Boston Soc. Nat. Hist. 8, p. 239, 240 (separated as "variety B").

Upperside:

Male. Both wings black-brown. A discal dark patch occupies the lower central part of the fore wing.

\section{Underside:}

Male. Both wings brown. Fore wing with a subapical, bipupilled ocellus, ringed with yellowish. Cell red, which color extends slightly into neighboring interspaces. There are two submarginal (outward of ocellus) lines, and an indication of a discal (basad of ocellus) line. Hind wing lightly overcast with a few scattered whitish scales. A single ocellus near the anal angle, with its small white pupil slightly basad of the center. A very obscure line crosses the basal part of the wing. Inward

${ }^{3}$ Godart, 1823, Encyclopedie Méthodique 9, p. 525. 
of the ocellus is a line, bluish near the costa, white thenceforwards. The two submarginal lines slightly converge towards the anal angle, and in the latter part are white in between. Basal to the inner submarginal line are three white spots, one each in the interspaces $\mathrm{M}_{2}-\mathrm{M}_{3}-\mathrm{Cu}_{1}$.

Length of fore wing, 12-13 mm.

Holotype, male, Debarriere, ${ }^{4}$ La Hotte Mt., Haiti, 4000 ft., Oct. 13, 1934 (P. J. Darlington). (M. C. Z. male genitalia slide no. 363.)

Paratype, male, same data.

Holotype, M. C. Z. no. 25916. Paratype in the author's collection.

Remarks. This subspecies differs from typical confusa ${ }^{5}$ in being darker below and with the light lines obscured. The cellular red is darker also. One male from Targi, near La Hotte, and a male from Ennery (both Haiti), seem referable to this subspecies, but both have slight differences.

\section{Calisto herophile parsonsi, new subspecies}

\section{Upperside:}

Male. Both wings brownish black, with the disk of the fore wings dull jet black.

Female. Similar to the male, but with the disk of the fore wing not quite so dark a black.

\section{Underside:}

Male. Fore wing rather dark brownish gray. Two submarginal lines, parallel, run from costa to inner margin. Basal to these, near the costa, is a rather large, black, and bipupilled ocellus, ringed with yellow. Basad of this ocellus is a discal line bordered outwardly, in the vicinity of the ocellus, with light scales. It is set perpendicular to the costa and approaches the submarginal lines near the anal angle. All of these lines are somewhat obscured towards the inner margin by a grayish shading, more or less distinct, that covers the whole lower half of the wing. A subtriangular reddish patch occupies the cell. Hind wing ground color similar to that of the fore wing, but slightly lighter. Two submarginal lines as in the fore wing, but

\footnotetext{
${ }^{4}$ Sometimes spelled "Desbarriere." I have adopted the name on the labels of the types, both as the type locality and in the formation of the new name.

${ }^{5}$ Lathy, 1899, Trans. Ent. Soc. London 1899, p. 227, pl. 4, figs. 12, 13.
} 
towards the anal angle whitish in between. A discal and a postbasal line cross the wing, the former basally limiting an area of dull bluish in which are four white spots, one to each of the Rs $-\mathrm{M}_{1}-\mathrm{M}_{2}-\mathrm{M}_{3}-\mathrm{Cu}_{1}$ interspaces, and a black, white-pupilled ocellus (reflecting bluish in some lights), ringed with yellow, in the $\mathrm{Cu}_{1}-\mathrm{Cu}_{2}$ interspace. The discal line is outwardly bordered by yellowish scaling, and the inner submarginal line, which outwardly borders this bluish area, is sometimes basally margined with light scaling. This bluish strip, while normally probably always present, appears to be very easily lost, since of the type series of 10 specimens, but three (the holotype, allotype, and one male paratype) have it; the three most perfect specimens. The remainder of the series consists of specimens fairly well flown, and all lack it. It is difficult to say, by examination of the specimens themselves, whether the absence or presence of this bluish is due to wear, but from an inspection of the series as a whole, it would appear that it was lost by prolonged flight.

Female. Similar to the male, with the following exceptions: the cellular red patch is larger; the ground color is slightly lighter; and the marginal area of both wings appears to be somewhat more whitish.

Length of fore wing; male, 14.5-16 mm.; female, 15-16 mm. Holotype, male, Buenos Aires, western Trinidad Mts., Prov. Santa Clara, Cuba, 3000 ft., June 19-21, 1939 (C. T. Parsons). Allotype, female, same data.

Paratypes, six males and two females, same data.

Holotype, allotype, and six paratypes, no. 25917 in the M. C. Z. A pair of paratypes in the author's collection.

Remarks. This race, in common with that of the Bahamas, apollinis ${ }^{6}$ is rather indistinct from the typical subspecies. The differences are slight, but seem in the specimens examined, to be quite constant. In appearance, at least, parsonsi seems to be most nearly allied to apollinis. The two may be separated by the darker ground color of parsonsi, and the latter's more distinct bluish band (when present). Parsonsi may be distinguished from the typical (described from Habana) ${ }^{7}$ in its

\footnotetext{
${ }^{6}$ Bates, 1934, Occ. Papers Boston Soc. Nat. Hist. 8, p. 136 (New Lepidoptera from the Bahamas).

${ }^{7}$ Hübner, J., 1823, Zuträge zur Sammlung Exotischer Schmetterlinge, 2nd Bund., p. 16, figs. 269, 270.
} 
darker ground color below, duller bluish band, and less distinctly marked lines.

Calisto herophile parsonsi seems to connect herophile (s.l.) and smintheus, ${ }^{8}$ but is quite definitely distinct from the latter. A pair, male and female, from Mina Carlota, in the Trinidad Mts. (1500 ft.), seem to agree with this subspecies.

This subspecies is named for the collector of the specimens, Dr. Carl T. Parsons.

Calisto pulchella darlingtoni, new subspecies

\section{Upperside:}

Male. Both wings dark brownish black. Fore wing with a large basal area of dull black scales, the scent patch. Hind wing with the inner marginal part of the wing lighter.

Underside:

Male. Fore wing dark brownish black, the base overlaid with dull fulvous hairs. Inner margin lighter, almost gray. The subapical ocellus is black, ringed with yellow and bipupilled, the second of which is placed in the margin of the ocellus. Between the ocellus and the outer margin there is an indication of two submarginal lines. Basal to the ocellus is another line, very faintly indicated, that crosses just beyond the cell and extends no further than $\mathrm{M}_{3}$. Hind wing with the ground color as in the fore wing. Base black with scattered fulvous scales. Disk of wing bright golden fulvous, running from costa, where it occupies the basal half of that margin (save for the extreme basal area of black), to the inner margin where it occupies the central two-thirds. Near the costa this fulvous area is crossed by a dark brown, rather sinuate line, parallel to the body axis. Just marginal to the fulvous, near the costa, is another, more obscure line, parallel to the first, but longer, and continuing to $\mathrm{M}_{3}$ where it enters the now expanded fulvous area, turns slightly and crosses it to the anal angle. Just outward of this line, in the $\mathrm{Cu}_{1}-\mathrm{Cu}_{2}$ interspace is a much elongated ocellus, ringed thinly with yellowish, and with the small white pupil at the basal end. Outer marginal border twice as thick on the costal half as on the anal half. An obscure post-discal parallels the outer margin, composed of obliquely set dashes. (Basal to this line, in the Rs $-M_{1}-M_{2}-M_{3}$ interspaces are three white dots, the first two

${ }^{8}$ Bates, 1935, Occ. Papers Boston Soc. Nat. Hist. 8, p. 242, fig. 9. 
between the discal and the above-mentioned line; the last on the discal line itself.) This line outwardly limits, near the anal angle, the discal fulvous area, but towards the costa it is set off only by a dull basal fulvous shading. The anal angle is black, basally capped by a curved white bar. A submarginal line is faintly represented, usually only towards the anal angle. The margin, at the anal angle, is irrorated with pale scales.

Length of fore wing, 19-20 $\mathrm{mm}$.

Holotype, male, Constanza, Republica Dominicana, Hispaniola, 3-4000 feet, Aug. 1938 (P. J. Darlington).

Paratypes, two males, same data as holotype; one male, foothills of the Cordillera Central, South of Santiago, Rep. Dom., June 1938 (P. J. Darlington).

Holotype and two paratypes, M. C. Z. no. 25918. One paratype in the author's collection.

Remarks. This subspecies differs quite noticeably from typical pulchella in the more extensive and more golden fulvous area beneath (on the secondaries). The discal and median lines that cross this fulvous area are thinner than in the typical race. The subanal ocellus of the hind wing is also much smaller, as is the subapical one on the fore wing. This subspecies has been compared with examples from Camp Perrin, Haiti ( $\pm 5000 \mathrm{ft}$.), and "Hayti, P. R. Uhler," that all agree well with Lathy's figures of pulchella. ${ }^{9}$ Incidentally, one of the museum's females of typical pulchella corresponds to the female form named tenebrosa (loc. cit. p. 225) by Lathy, and figured by him (fig. 7). It would appear to be only a minor variant, hardly worthy of a name.

This subspecies is named for Dr. P. J. Darlington, Curator of Coleoptera at the Museum of Comparative Zoölogy.

${ }^{9}$ Lathy, 1899, Trans. Ent. Soc. London, 1899, p. 225, pl. 4, figs. 5, 6, 7. 

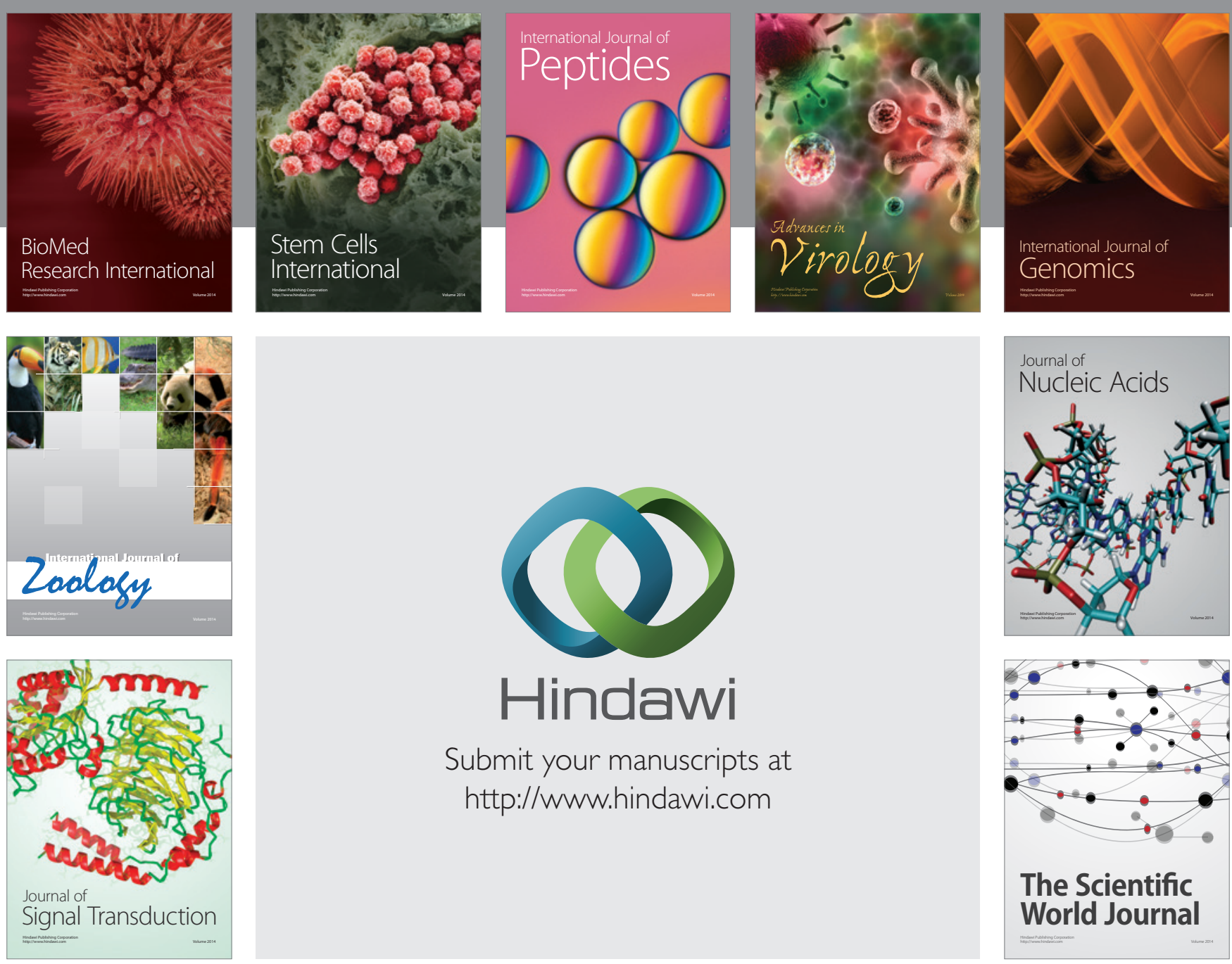

Submit your manuscripts at

http://www.hindawi.com
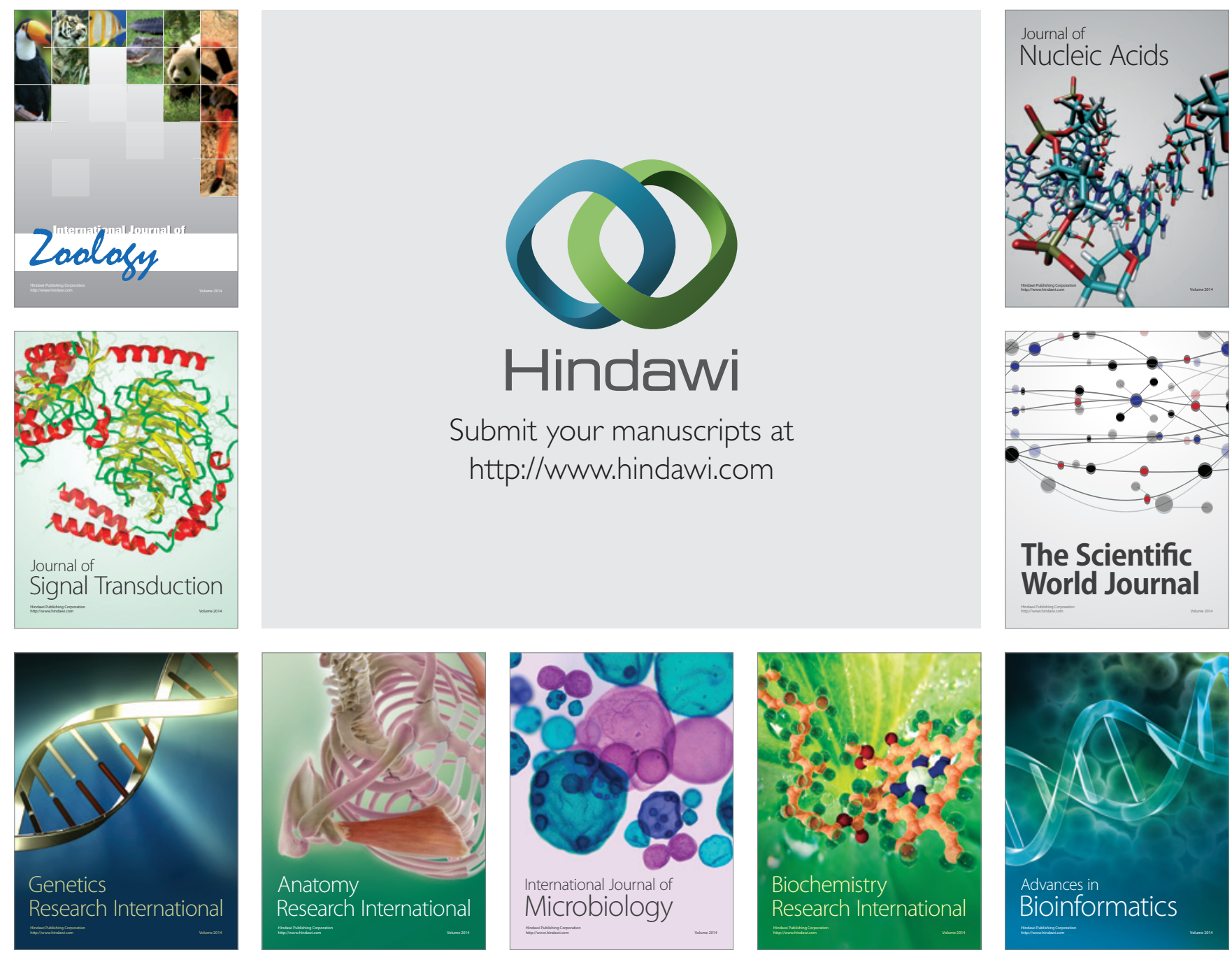

The Scientific World Journal
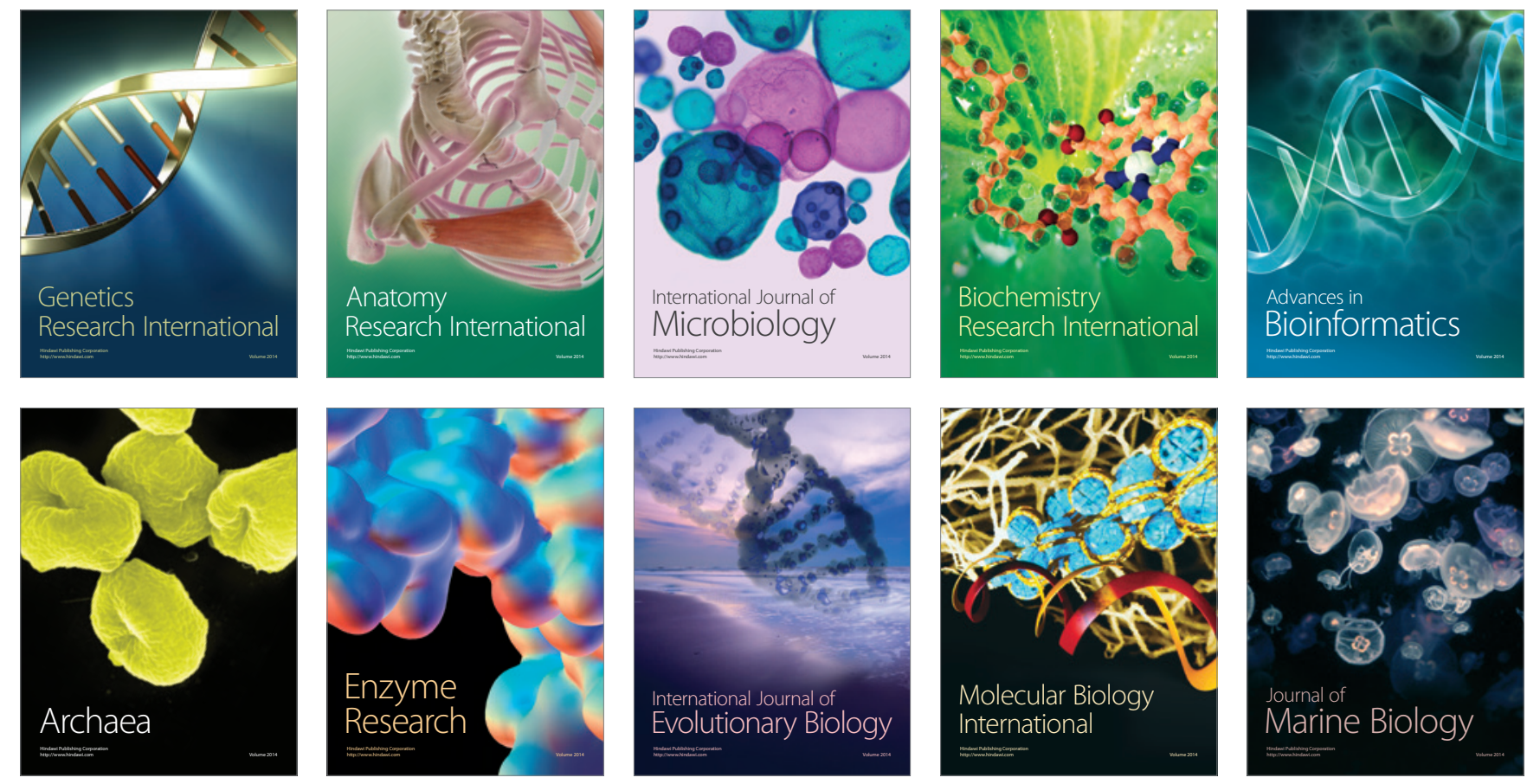